\title{
"ON ABSOLUTE MORALITY"
}

Nyack, New York Sir: Worldview is fond of the word "ambiguity" in international affairs. Unless I am mistaken, it seems to afford for you a moral blank check as an alternative to the too rigorous absolutes of the Christian Gospel.

But what about the intra-national ambiguities within countries where tyranny rules? Surely there is no reason to soften our criticism of the lack of civil liberty in the Communist countries. But we should recognize two things. First, the fact that no matter how "hard" or "soft" the Soviet leaders may be at a given time, the people of the USSR are not now and never have been our enemies. Yet U.S. policy has never been directed toward means of removing or annihilating the leaders only; it has consistently developed methods for annihilating the very people we would rescue from the dictators.

Second, the "softening" or liberalization of Soviet life during the past six years must be kept constantly in view. We must not lose our perspective. There is no reason for not applauding a man like Boris Pasternak and protesting any censure of him by the Soviet State; indeed I have so applauded and protested. But in the same context we should note with gratitude the mildness of the censure and compare it with the fate of men like Meyerhold and Babel. Likewise we should consider, for example, the fact that medical care is supplied free to everyone in the USSR, and that the USSR is training at least twice as many M.D.'s as is the U.S.

You tend, I fear, to see Communism as so black that you can weigh it against nuclear annihilation. Even if we had to deal with the blackest of Soviet tyranny at its Stalinist nadir, there would at least remain some glimmer of a redemptive posssibility. $A$ war with $A B C$ weapons would extinguish that possibility entirely.

To be sure, there are penultimate choices to be made. But if the ultimate choice is between treason to the United States and treason to humanity before Almighty God, there may be some (count me among them!) who would choose treason to their nationhood. Do you think you will be forgiven for slaying Russian children in their beds for the sake of American liberties? Do you even think that those liberties could be preserved'in any meaningful way in the nuclear holocaust?

WILLIAM ROBERT MILLER

\section{"LIBERTY OR DEATH"}

New York, N.Y. Sir: I see that the Committee for Constitutional Government wants Worldview to apologize to Congress, on pain of being "indefinitely suspected of treason." I couldn't sleep last night for wondering what you are going to say in your letter of apology. (I assume you do not want to spend the rest of your life under suspicion of having some reservations about letting everybody in the U.S. be killed for the sake of saving the U.S.)

On the technicalities: I guess you would address identical letters to the Speaker of the House and the President of the Senate. And you would ask that the letters be entered in the Congressional Record. The letter could end with "Abjectly yours." Now, with respect to what you would put between the opening and ending, I tried a couple of drafts but could not seem to make the sentences sound sufficiently humiliated and abject. This may be because I am an American citizen and a Christian, and those annoying documents, the New Testament and the U.S. Constitution, always insinuated themselves into my mind, just when I thought I had a good ringing sentence. Recalling Mayor La Guardia's classic statement, I had as my opening sentence: "When Worldview makes a mistake it's a beaut."

On second thought, you might well ask Mr. Willford I. King to compose a letter for you. His letter should describe what the Congress did, what you said, and the reasons for believing you made an awful mistake. This would make interesting reading.

On third thought, you could send a copy of the Bible and a copy of the Constitution to both houses of Congress, with a covering letter saying that these constitute your apology. But, on further thought, this does not seem adequate.

I am going to stay awake one more night trying to help you and if a good letter does not form itself in my mind, I am going to forget the whole thing. HERMAN F. REISSIG 